\title{
The Indigenous Watercraft of Northern Eurasia
}

\author{
W. W. Fitzhugh, H. T. Luukkanen
}

For citation: Fitzhugh W. W., Luukkanen H. T. The Indigenous Watercraft of Northern Eurasia. Vestnik of Saint Petersburg University. History, 2019, vol.64, issue 2, pp. 474-498.

https://doi.org/10.21638/11701/spbu02.2019.206

Hear we overview the indigenous watercraft from northern Europe to Bering Strait and the Far East. Our purpose has been to document the types of boats, their history, and how they were made and used by the cultures of this vast region. Data have been gleaned from diverse sources, including archaeological finds, ethnographic descriptions, museum collections, photographs, historical documents, and reports of early trans-Siberian travelers. Because of space limitations, the summary provided here is devoted to bark boat traditions, with limited discussion of skin boats because the latter are better known in existing literature. Our work has been facilitated by Valentina V. Antropova, whose 1961 survey of Soviet/Russian watercraft guided much of our work. We describe four major canoe traditions, each coinciding with major river systems: Ob-Pechora, Yenesei, Lena, and Amur. Within each river system there may be several sub-types, e. g. Amur I and Amur II. Except in rock art, the history of bark boat development is very shallow as very few bark canoes have been preserved archaeologically. Paddles, however, indicate the presence of bark canoes as early as 8000 years ago. Some rock art depicts log canoes rather than bark or skin boats. Wooden planked boats replaced bark

Harri T. Luukkanen - independent researcher, Hiihtomäentie, 33B, 19, 00800 Helsinki, Finland; Harri.Luukkanen@gmail.com

Харри Т. Луукканен - независимый исследователь, Финляндия, Хельсинки, 00800; Хиихтомаенти, 33Б 19; Harri.Luukkanen@gmail.com

William W. Fitzhugh - PhD in Anthropology, Senior Scientist, Smithsonian Institution's Arctic Studies Center and curator of North American archaeology, $10^{\text {th }}$ St. \& Constitution Ave, NW Washington, D.C., 20560, USA; Fitzhugh@si.edu

Вильям В. Фиихью - д-р философии (антропология), ст. науч. сотр., Центр Арктических исследований Смитсоновского Института, фонд археологии Северной Америки. США, округ Колумбия, Вашингтон, 20560, 10-я ул. и пр. Конституции; Fitzhugh@si.edu

Our work on North Eurasian watercraft has been facilitated by so many individuals and organizations that it is impossible to adequately convey our appreciation in the space allowed here. Over the past decade, Harri Luukkanen has consulted hundreds of individuals and scores of museums, libraries, and archives ranging from Western Europe to the Far East. Harri conducted most of the basic research and initial drafting of the book manuscript, while Fitzhugh worked around the edges, elaborating, re-writing, and filling in anthropological and archaeological knowledge. In addition to the large number of partners unmentioned here, we can at least thank our families and spouses, a score of Smithsonian's Arctic Studies Center interns, and Marcia Bakry and Dan Cole for drawings and maps.

Работе над нашей статьей о судостроении аборигенов Северной Евразии способствовало так много людей и организаций, что невозможно передать нашу благодарность несколькими словами. За последнее десятилетие Х. Луукканен проконсультировался с множеством сотрудников различных музеев, библиотек и архивов от Западной Европы до Дальнего Востока. Х. Луукканен провел большую часть базовых исследований и подготовку для первоначального составления рукописи, в то время как В. Фицхью занимался работой с антропологическими и археологическими данными. В дополнение к большому количеству партнеров, не упомянутых здесь, мы можем, по крайней мере, поблагодарить наши семьи и стажеров Смитсоновского центра арктических исследований, а также Марсию Бакри и Дана Коула за рисунки и карты.

() Санкт-Петербургский государственный университет, 2019 
canoes in northwestern Eurasia during the late Iron Age but persisted in the Amur into the $20^{\text {th }}$ century. Canoes appear to have dispersed from South Siberia during the early Holocene and developed distinctive features in their respective river systems. Some Ket Yenesei canoe styles may be prototypes of Kootenai Indian canoes of interior British Columbia.

Keywords: indigenous watercraft, bark canoe, boat history, archaeology, canoe types, construction, functions

\section{Аборигенное судостроение Северной Евразии}

\section{В. В. Фиихью, Х. Т. Луукканен}

Для цитирования: Fitzhugh W. W., Luukkanen H. T. The Indigenous Watercraft of Northern Eurasia // Вестник Санкт-Петербургского университета. История. 2019. Т. 64. Вып. 2. С. 474-498. https://doi.org/10.21638/11701/spbu02.2019.206

Настоящая работа содержит обзор источников по аборигенному судостроению от Северной Европы до пролива Беринга и Дальнего Востока. Цель исследования состоит в документации типов лодок, их истории, а также процессов их изготовления и использования в культурах этой обширной территории. Представленные данные собраны из разнообразных источников, включая археологические находки, этнографические описания, музейные коллекции, фотографии, исторические документы и записки первых путешественников, посетивших Сибирь. В настоящей работе мы уделяем большее внимание традиции строительства лодок из древесной коры, в меньшей степени обсуждая лодки с кожаным покрытием, поскольку последние известны гораздо лучше. Данная работа восходит к труду В.В.Антроповой, чье исследование лодок народов СССР/ России, опубликованное в 1961 г., послужило для нас руководством. Мы описываем четыре основных наиболее важных традиции строительства каное, совпадающие с основными речными системами Северной Евразии: Обско-Печорской, Енисейской, Ленской и Амурской. В пределах каждой из них могут быть выделены некоторые подтипы, например Амур I и Амур II. За исключением наскальных изображений, история развития традиций строительства лодок из древесной коры малоизвестна, поскольку они представлены всего несколькими археологическими находками. Находки весел тем не менее указывают на существование лодок из коры по крайней мере 8000 л. н. Некоторые наскальные рисунки изображают лодки-долбленки, а не лодки, крытые корой или кожей. В Северо-Западной Евразии деревянные лодки из досок замещают лодки из коры в позднем железном веке, но продолжают существовать на Амуре в ХХ столетии. Представляется, что каное распространяются из Южной Сибири в раннем голоцене и приобретают своеобразные черты в различных речных системах. Некоторые стили каное енисейских кетов могли быть прототипами каное индейцев Коутенай во внутриматериковых районах Британской Колумбии.

Ключевые слова: аборигенный водный транспорт, каноэ из коры, история лодки, археология, типы каноэ, конструкция, функции.

In 1964, the Smithsonian Institution published Bark Canoes and Skin Boats of North America authored by Edwin Tappan Adney and Howard I. Chapelle. By that time, the Smithsonian had been collecting Native American artifacts and watercraft for more than a century. Yet, except for a report by Otis Mason and Meriden Hill ${ }^{1}$ and a description of

1 This paper is a condensation of a book the authors have prepared titled Bark Canoes and Skin Boats of the Eurasian North, to be published in 2019 by Smithsonian Books and Random House (Mason Otis T., 
building a Chippewa birch-bark canoe by Robert Ritzenthaler ${ }^{2}$, anthropological literature on indigenous North American watercraft was largely anecdotal. For the first time, Adney and Chapelle had provided scholars and general readers with a comprehensive study of canoes and kayaks in North American collections that included detailed descriptions, ethnographic data, photographs and drawings, and information on use, decoration, and ritual. Despite its monographic style, the book became so popular that it remained in print ever since. The opportunity to prepare a comparable work prompted the present authors to undertake a sequel for the Eurasian continent. Bark and Skin Boats of the Eurasian North describes the history, use, and types of bark and skin boats utilized by the traditional cultures of northern Eurasia. The book serves as an historical atlas of traditional boats among more than forty tribes and peoples from northern Europe to Central Asia and the Far East.

\section{The Tappan Adney Legacy}

Tappan Adney was a renaissance individual - artist, naturalist, woodsman, linguist, and scholar. At age 19, while Adney was vacationing in Woodstock, New Brunswick, a Maliseet Indian named Peter Joe taught him how to make a bark canoe. Soon Adney became fascinated with American Indians, Indian lore, and, in particular, their canoes and canoe traditions. His early curiosity about Indian watercraft developed into a lifetime spent documenting canoes and kayaks in museums and Native communities across North America $^{3}$. He documented manufacturing techniques, raw materials, and vessel performance; he interviewed and photographed Native Americans making canoes and used this information to build scale models and make nautical-style drawings of canoe lines, and sketches of construction details. Late in life, he sold his models and willed his voluminous archives to the Mariner Museum in Newport News, Virginia (Fig. 1). Following Adney's death in 1950, Howard Chapelle, a marine architect and curator of naval history at the Smithsonian National Museum of American History, organized Adney's materials into a monographic study. Its ethnographic descriptions and photographs provided a window onto a long-neglected and mostly vanished part of North American Native life, and its construction drawings enabled recreational boat-builders to make authentic replicas for the first time.

While the history of European plank boats has been discussed by many authors ${ }^{4}$, there has been relatively little synoptic literature on traditional watercraft covering the entire region of northern Eurasia. Rudolf Trebitsch ${ }^{5}$ wrote on the origin and distribution

Meriden S. Hill. Pointed Bark Canoes of the Kutenai and Amur. Report of the U.S. National Museum for 1899. Washington, 1901. P. 525-537).

2 Ritzenthaler R.E. The Building of a Chippewa Indian Birch-Bark Canoe // Bulletin of the Public Museum of the City of Milwaukee. Vol. 19(2). 1950. P.59-98.

3 Adney T.E., Chapelle H. Bark Canoes and Skin Boats of North America. Washington, 1983. P.4; Jennings J. The Art and Obsession of Tappan Adney. Toronto, 2004.

${ }^{4}$ Johnstone P. The Seacraft of Prehistory. Cambridge, 1980; McGrail S. Ancient Boats in NorthWest Europe: The Archaeology of Water Transport to AD 1500. New York, 1998; Crumlin-Pedersen O. Archaeology and the Sea in Scandinavia and Britain: A Personal Account. Maritime Culture of the North 3. Roskilde, 2010.

${ }^{5}$ Trebitsch $R$. Fellboote und Schwimsäcke und ihre geographische Verbreitung in der Vergangenheit und Gegenwart // Archiv für Anthropologie. Neue Folge, Bd. XI. 1912. S. 61-84. 


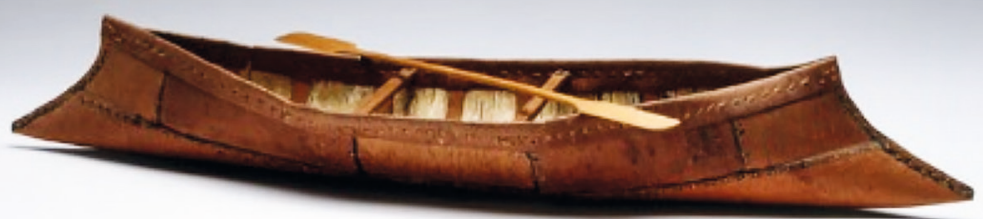

Fig. 1. Yakut Canoe Model. Adney made this model based on Otis Mason's 1901 publication of a model Yakut canoe (MAE 701-51) collected by Alexander Fedorovich von Middendorf in the Lena River valley in 1846. The MAE model was loaned to the Smithsonian to facilitate Mason's comparative study of North American canoes (Mariner's Museum photo MP48)

skin boats in Europe; H.H. Brindley ${ }^{6}$ reported on boats of Siberia based on reports of early explorers and navigators; and Scandinavian skin boats have been discussed by Westerdahl ${ }^{7}$. There is also an early global summary of skin and bark boats ${ }^{8}$ and on bark boats of East Africa ${ }^{9}$. Three years before Adney's and Chapelle's book appeared, Valentina V. Antropova ${ }^{10}$, a researcher in the Ethnography Department of the Peter the Great Museum of Anthropology and Ethnography, also known as the Kunstkamera in St. Petersburg, published a chapter titled "Boats" in the Kunstkamera's 1961 Historical-Ethnographical Atlas of Siberia. Antropova's paper described northern Russia's indigenous bark canoes, dugouts, planked boats, kayaks, and large skin boats for each major ethnographic group and offered a typological classification of the different boat types. Antropova recognized that because Siberia lacked Europe's Roman literature, her primary sources would be ethnographic and historical.

\section{North Eurasian Boat Types}

In her "frame boat" class, Antropova identified three birch-bark canoe types, which she named after the river systems where they had been found. The Yenisey type has a pointed, overhanging bow and stern. The Lena type has a rounded, upturned bow and stern projection, a partially enclosed cockpit, and gunwales that do not extend the full

${ }^{6}$ Brindley H. H. Notes on the Boats of Siberia // Mariner's Mirror. 1919. No. 5(4). P.66-72; No. 5(5). P. 130-142; No. 5(6). P. 184-187.

7 Westerdahl Ch.: 1) Sewn Boats of the North: A Preliminary Catalogue with Introductory Comments. Part I // International Journal of Nautical Archaeology and Underwater Exploration. No. 14(1), 1985. P. 33$62 ; 2)$ Sewn Boats of the North: A Preliminary Catalogue with Introductory Comments. Pt. II // International Journal of Nautical Archaeology and Underwater Exploration. No. 14(2), 1985. P. 119-142

${ }^{8}$ Nishimura Sh. A Study of Ancient Ships of Japan. Pt. 4: Skin Boats. Tokyo, 1931.

9 Arnold B. Les pirogues kapepe, l'espace nautique du bassin de la rivière Malagarasi (Tanzanie) et quelques observations sur les pirogues en écorce d'Afrique orientale. Le Locle, 2014.

${ }_{10}$ Antropova V. V. Boats // Historical-Ethnographic Atlas of Siberia / eds M. G. Levin, L. P. Potapov. Moscow, 1961. 


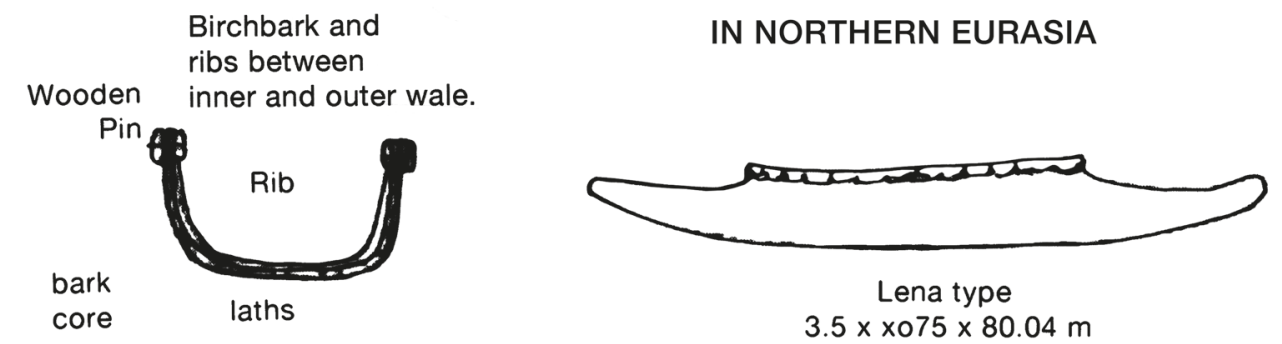

\section{MAJOR BIRCH BARK CANOES \\ IN NORTHERN EURASIA}

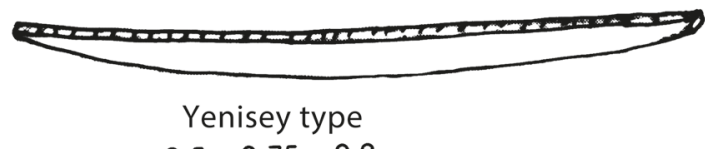

$3.5 \times 0.75 \times 0.3$
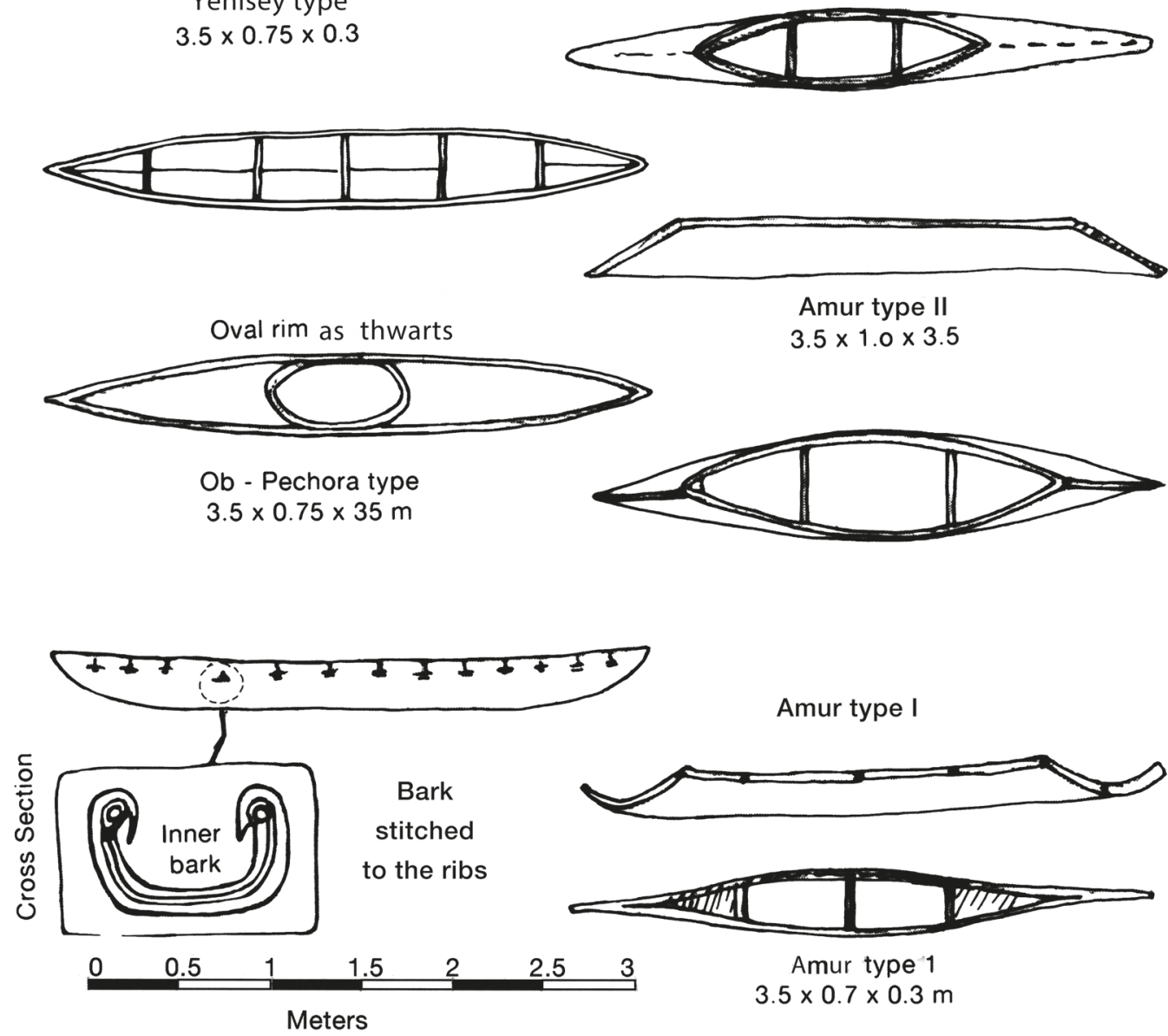
Bakry)

Fig. 2. Canoe types of the Russian North and Far East (drawing by Harri Luukkanen and Marcia

length of the boat. The Amur type has bow and stern projections, a narrow beam, and sometimes partially covered bow and stern decks. Birch bark was the preferred material for all three types. Antropova's skin boat classification has two types. The large, open skin 
boat is defined by a keel running down the middle of the vessel's bottom to which ribs that curve upward to the gunwales are attached. Although adding weight, the keel adds longitudinal strength needed for use in rough maritime regions. This large, open-top, skin-covered bidara was used by Chukchi and Pacific coastal groups in northeastern Siberia for long-distance travel, trade, and hunting whales and walrus. It was called angyapik by the Chukchi and Yupik Eskimo, umiak by the Alaskan and Canadian Inuit, and angyaq by Kodiak Alutiit. The second type is the smaller, fully-decked, skin-covered kayak used on both sides of Bering Strait and throughout Arctic North America as a hunting craft propelled by single, double, or occasionally in the Aleutian Islands, by three paddlers, said to have been an innovation to accommodate a Russian trade boss.

Although Antropova was primarily concerned with the description and geographic distribution by ethnic group, like Trebitsch, she also had ideas about boat history. She commented on the widespread distribution of the bark canoe, which was replaced in Western Siberia and the Okhotsk region first by expanded log boats and later, following Russian contact with Native groups in the $17^{\text {th }}$ to $19^{\text {th }}$ centuries, by plank boats. Based on linguistic data, she speculated that the birch-bark canoe probably originated in the taiga forest zone of southern Siberia. She also commented on the northeastern Siberian distribution and probable origin of skin-covered bidarkas and kayaks, which she identified as the most specialized and ancient of all known Russian indigenous boats, among interior reindeer hunters. Citing Rudenko ${ }^{11}$ and Arutiunov's and Sergeev's ${ }^{12}$ finds at Ekven, she noted that models of boats similar to ethnographic skin-covered umiaks and kayaks were recovered from Old Bering Sea and Punuk archaeological sites in coastal Chukotka dating ca. 1,500-800 and 1,200 years ago, respectively. She also remarked that $16^{\text {th }}$-century exploration literature contains illustrations of kayak-like boats used by Nenets maritime hunters and their neighbors in the Barents and Kara Seas ${ }^{13}$.

The classification system used in our survey largely follows Antropova's taxonomy but recognizes five rather than three bark canoe types (Fig. 2). We follow Antropova's Yenisey and Lena types, split her Amur type into two sub-types (Amur I and II), and identify a new Ob-Pechora type. In addition, our study of keeled skin boats recognizes more variation in the open and closed types than Antropova's. We classify the kayak group into several ethnic-based sub-types, including Yukagir, Eskimo-Chukchi, Koryak, and Kuril/ Ainu. Our open skin boat classification follows Antropova's two types: the Eskimo-Chukchi type of Chukotka and the Koryak-Kerek type of northern Kamchatka.

\section{Description of Canoe Types}

Bark canoes were used by all aboriginal peoples living in Northern Eurasia's boreal forest. The era of birch-bark canoe lasted until the $18^{\text {th }}$ century in most of Eurasia and a century or two longer in parts of eastern Siberia and the Far East. Canoe type areas usually follow the large river basins of the Pechora-Ob, Yenisey, Lena, and Amur River homelands

${ }_{11}$ Rudenko S. I. Early Harpoon Heads of the Asiatic Eskimo // Sovietskaia Etnografiia. Moscow, 1947. No. 2. P.33-56.

12 Arutiunov S. A., Sergeev D. A. Problems of Ethnic History in the Bering Sea: The Ekven Cemetery. Transl. by R. L. Bland. Anchorage, Alaska, 2006.

${ }^{13}$ Belyavsky F. O. A Trip to the Arctic Sea. St. Petersburg, 1833 (see: 2007 Khanty-Mansiysk: FGUK State Historical Museum). 
of the people who used these boats. Each river drainage area had its own typical canoe design, and these types often were shared across linguistic and ethnic borders. The close linguistic and cultural relations among the various groups living along a single river system facilitated sharing, and their canoe traditions tended to cluster in a similar fashion.

The Yenisey type has strong double gunwales that sandwich both the horizontal lath planking strips and the vertical ribs, a technique still used in modern wood canoe construction today. The Lena type with more or less vertical bow and stern profiles was used by Evenk and Sakha peoples living around the eastern portions of the Vitim and Olekma rivers, eastern tributaries of the Lena. In addition to this type, people living in the Lena basin also used canoe types known from the Yenisey and Amur systems due to population migrations and adoption of neighboring canoe technology.

Amur canoes occur in two main forms. Amur I has long projecting bow and stern extensions resembling "beaks" that turn upward at their ends, while Amur II is a short canoe with straight, pointed extensions at the waterline. The longer Amur I type typically had a beam of 70 centimeters, a strong bottom construction using as many as five bark layers glued together, and an interior keel running from end to end. Wooden blocks were sewn into the bark sheets to support the gunwales at the bow and stern. Because its hull design resisted flexing, the Amur I type could be made very long - as demonstrated by a 15-meter-long bark canoe found on the Maya River, a tributary of the Aldan. The Amur II-type canoe, originally described by Otis Mason as a "sturgeon-nose" canoe because its ends or "beaks" resembled a sturgeon's snout, was short, had rather weak gunwales, and could carry only a single person. Beyond the Amur, the Amur II type was known in the upper (southern) Lena River locations where Evenk people of Amur origin resided. Most Amur basin people were Tungus-related, and all made similar bark canoes.

Our proposed Ob-Pechora type bark canoe originated in Southern Siberia, where it was used by Samoyed and shared with Ob-Ugrian peoples; from there, it diffused throughout Western Siberia between the Pechora and the Yenisey Rivers. Evidence for this canoe type comes from several sources: Kamas canoe construction on the Yenisey River documented in G. F. Miller's 1730-1740 "Description of Siberian Peoples"14; a drawing of a Mansi or Khanty boat in Obdorsk made by Tobias Königsfeld in $1728^{15}$; a Khanty model in the Swedish Ethnographic Museum collected by F. R. Martin on the Tobol River in 1895; a bark canoe model from the Amgun River (MAE 5333); and Samoyed oral evidence from Narym ${ }^{16}$.

The Ob-Pechora type occurred in the middle Ob-Irtysh-Tobol area occupied mainly by the Samoyed (Nenets, Selkup, and Kamas-Koibal) and Ob-Ugrian (Khanty and Mansi) peoples. This canoe type was found among Turkic Tatars in the south Siberian taiga and was shared with western Ural peoples in the Mezen-Pechora taiga of northeastern Europe. Its main differences from the Yenisey type are: (1) presence of an oval rim instead of transverse thwarts, known among the Eastern Khanty; (2) a single rather than a double gunwale strake; (3) passing the bark over, rather than between, the gunwales; and (4) a

14 Vermeulen H.S. Ethnography and Empire. G. F.Müller and the Description of Siberian Peoples // Before Boas. The Genesis of Ethnography and Ethnology in the German Enlightenment. London, 2016. P. 131-218.

${ }^{15}$ De Lisle N., Königsfeld T. Extract de Voyage un Sibirie M. DeLisle \& Journal de M. Königsfeld en 1740 // Francois Antoine (1768), Histoire générale des voyages, voyage de Sibiria. Paris, 1768.

16 Pelikh G. I. Proiskhozhdenie selkupov. Tomsk, 1972. 
different method for fastening the gunwales. The latter involved lashing the gunwales together fifty centimeters from their ends, thus creating a narrow top profile for bow and stern. In the $\mathrm{Ob}$ canoe, the gunwale ends were not pinched together but were fastened to separate pieces of bent wood. The rounded ends provided more cargo space and buoyancy and reduced taking on wave water. On the middle $\mathrm{Ob}$, Khanty canoe builders doubled the birch-bark bottom by inserting an additional bark layer inside the outer shell. In other features, the Yenisey and Ob-Pechora canoes were similar.

Despite the great distances and multiple ethnic groups occupying the region from the Yenisey to the Pechora, the similarities between the canoes of this region probably results from two factors: migration history of the past 1,000 years, and the intense interactions of long-distance traders during the Russian fur-trade era. The Khanty, Nenets, and Mansi were constantly trading and warring with one another across the Ural passes. Until circa 1470, many Mansi lived on the European side and held lands reaching as far west as the Dvina River ${ }^{17}$, where their traders were in contact with Karelian groups. This could account for the similarity in canoe styles between the $\mathrm{Ob}$ and the Mezen-Pechora taiga. Archaeological, linguistic, and DNA data ${ }^{18}$ suggest that the eastern Saami peoples who once lived along the southern White Sea coast had contacts with groups living in the CisUrals $^{19}$. It is likely that the Saami birch-bark canoe types as they are known today from oral descriptions and remains found in northern Sweden, were also similar to Mansi or Samoyed canoes known from the White Sea.

Here, as in other areas of Eurasia, Antropova's and our studies indicate that geographic proximity along a single river system generally was a more important factor than either language or ethnicity in determining the geography of boat types. This principle confounds the typological changes usually seen across cultural-historic and ethnolinguistic borders. In his study of northeastern European paddle types, Grigori Burov ${ }^{20}$ found that he could date different types of paddles to a certain millennium, beginning as early as 8700 BP. In this case, chronology rather than culture seems to have been the dominant factor determining a paddle form. By contrast, from the $19^{\text {th }}$ century ethnographic data, Otis Mason ${ }^{21}$ found that the shapes of paddles from different Amur cultures were good indicators for the ethnic groups who made them. Similarly, style shifts in Eskimo kayak and paddle types from Alaska to Greenland show strong correlation with ethnic and language areas ${ }^{22}$.

Recent research at the 8500 BCE Mesolithic site at Star Carr by Peter Rowley-Conwy ${ }^{23}$ reviewed the scant information on bark canoes in North European prehistory. Noting

17 Sokolova Z.P. The Mansi. Moscow, 1983.

18 Tambets K. et al. The Western and Eastern Roots of the Saami - The Story of Genetic 'Outliers' Told by Mitochondrial DNA and Y Chromosomes // American Journal of Human Genetics. No. 74(4). 2004. P. 661-682.

19 Foss M. E. Kul'turnye sviazi severa Vostochnoi Evropy vo II tysiacheletiiu do nashei ehry // Sovetskaia Etnografiia. 1948. No. 4. P.23-35.

${ }^{20}$ Burov G. M. On Mesolithic Means of Water Transportation in Northeastern Europe // Mesolithic Miscellany. No. 17. 1996. P.5-15.

${ }^{21}$ Mason O., Meriden Sh. Pointed Bark Canoes of the Kutenai and Amur. Report of the U. S. National Museum for 1899. Washington, DC, 1901. P. 525-537.

${ }^{22}$ Rousellot J.-L. Watercraft in the North Pacific: A Comparative View // Anthropology of the North Pacific Rim. Washington, 1994. P.243-258; Golden H. Kayaks of Alaska. Portland, 2015.

${ }^{23}$ Rowley-Conwy P. To the Upper Lake: Star Carr Revisited - by Birchbark Canoe // Economic Zooarchaeology: Studies in Hunting, Herding, and Early Agriculture. Chapter 23. Oxford, 2017. 
finds of birch resin and bark sheets in water-logged Mesolithic sites, Rowley-Conwy believes birch-bark canoes were the usual vehicles for exploiting post-glacial wetland environments. Undoubtedly, the same could be said for post-glacial northern Eurasia, where 8700 year old paddles indicate water transport.

\section{Geography of Bark Canoes Types}

When we began our canoe project, we thought that careful comparison of boat types would enable us to make a rough synthesis of Northern Eurasian boat history by using a combination of construction form controlled for both spatial and chronological dimensions (Figs 3, 4). This approach, which is the normal basis for archaeological reconstruction, had a practical disadvantage due to the limited knowledge of canoe history, even for the past 500 years. This type of historical data does exist for plank boat development in the Mediterranean and Western Europe for the past 2,000 years ${ }^{24}$. Reconstructing such a data matrix was the goal of early attempts at a global evolutionary framework of boat development based on ethnographic data, as seen, for example, in James Hornell's ${ }^{25} \mathrm{Wa}$ ter Transport: Origins and Early Evolution. Hornell encountered many of the same problems we faced, including insufficient archaeological and historical data. In the case of bark canoes and skin boats, we are limited to a few centuries of historical documentation, ethnographic boat models, rare archaeological finds, and rock art images of problematic interpretation. Our birch-bark canoe data matrix, which includes only data from the end of the $18^{\text {th }}$ century onward, is not a reliable database for understanding 10,000 years of canoe form and construction. Although a sporadic 8,700-year development is known for paddles, they tell us little more than the size of the canoes. Nevertheless, one thing is clear: the movements of people hunting, fishing, trading, warring, and migrating in the taiga zone have been hugely successful in spreading bark canoe technology into all corners of Eurasia and throughout Northern North America.

We must remark on an exception in the general absence of data for Europe west of the Ob River. The Saami bark canoe, although being closest to Europe's technological heartland, lasted longer than bark canoes in other areas of northeastern Europe and Scandinavia. There is some evidence that the birch-bark canoe survived as a rarity until the early 1800s in Swedish Lapland, where oral literature and archaeological sites reveal evidence of bark canoes ${ }^{26}$. Remains of an undated birch bark canoe of Saami or Karelian origin have been found in the Lake Saimaa region of eastern Finland, although not enough was preserved to determine its type classification ${ }^{27}$. In Europe, the use of the birch-bark canoe faded early because of the appearance of the expanded log boat, which replaced it in

24 McGrail S. Ancient Boats in North-West Europe: The Archaeology of Water Transport to AD 1500. New York, 1998; Christensen A. E. Ships and Navigation // Vikings: the North Atlantic Saga. Washington, 2000. P.86-97; Crumlin-Pedersen O. Archaeology and the Sea in Scandinavia and Britain: A Personal Account. Maritime Culture of the North 3. Roskilde, Denmark, 2010.

25 Hornell J. Water Transport: Origins and Early Evolution. Newton, 1970.

26 Westerdahl Ch. Sewn Boats of the North: A Preliminary Catalogue with Introductory Comments. Pt. I // International Journal of Nautical Archaeology and Underwater Exploration. No. 14 (1), 1985a. P. 3362; Westerdahl Ch. Sewn Boats of the North: A Preliminary Catalogue with Introductory Comments. Pt. II // International Journal of Nautical Archaeology and Underwater Exploration. No. 14 (2), 1985. P. $119-42$.

27 Itkonen T.I. Suomen Ruuhet: 1-, 2-, 3-Ja Monipuiset Sekä Lautaruuhet Kivikaudesta Vuoteen 1940. Forssa, 1942. P. 48. 
Users: Samoyed, Khanty, Mansi, Users: Samoyed, Ket, Evenki Users: Yukaghir, Evenk, Lamut, Sakha Users: Nanai, Negidal, Nivkh

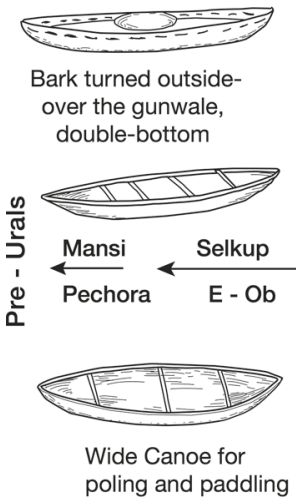

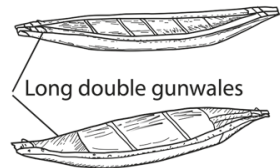

Half - decked, Covered with Bark or Skin

Evenki,

E- Yenisey

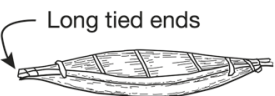

Big Variation in size, Canoes made for 1-6 persons

(C) H. Luukhanen May 9, 2014

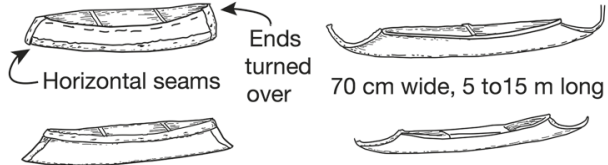

Half - decked

Covered with Bark or Skin

Half-decked, vertical or dull ends Evenki, Sakha $\leftarrow$ E - Lena

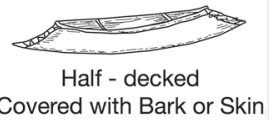

Evenki, Sakha

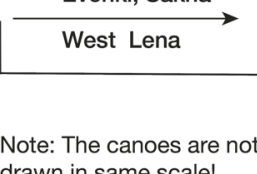
drawn in same scale! $\stackrel{\text { Amur - Evenk }}{\longrightarrow}$

Canoe size veriation Very large: Beam 0.5-0.5-1.5m Length $4-10 \mathrm{~cm}$

Fig. 3. Geography of canoe types across northern Eurasia (drawing by Harri Luukkanen and Marcia Bakry)
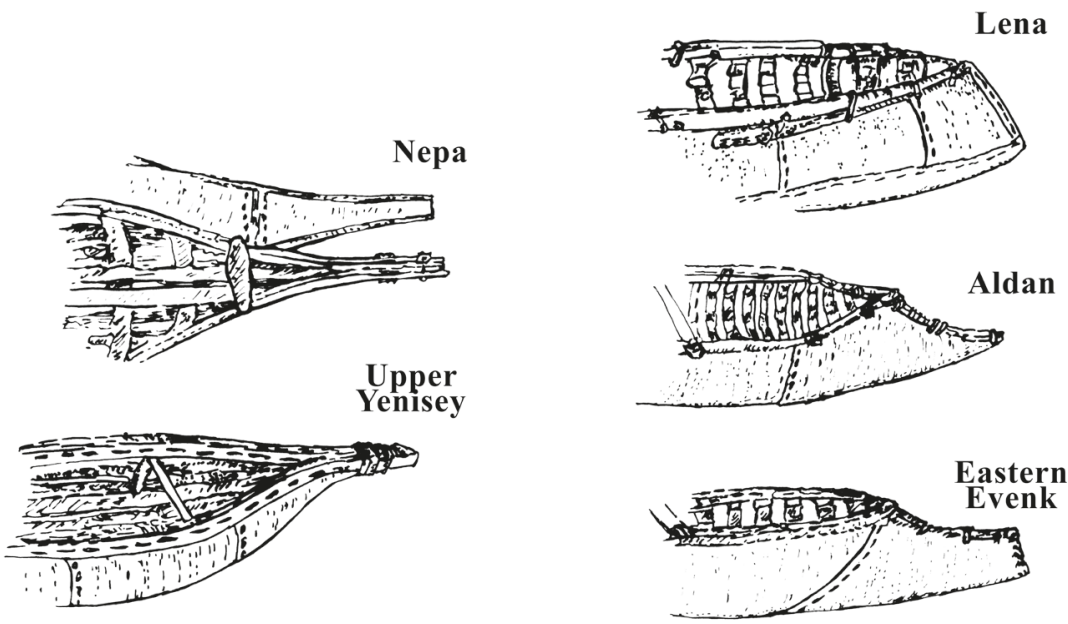

Fig. 4. Canoe construction variation in Central and Southern Siberia (drawing by Harri Luukkanen)

the taiga during the Late Medieval period and may have superseded the skin boat in the tundra zone. This phenomenon may have taken place when the Saami-Karelian people invented or adopted expanded log boats to which planks could be attached, providing higher sides to keep out water ${ }^{28}$.

The canoes of the eastern $\mathrm{Ob}$ and western Yenisey River basins conform to a single type, within which there is significant diversity owing to the complex history of the peo-

${ }^{28}$ Luukkanen H. On the Diffusion of Bark Canoes, Skin Boats and Expanded Log Boats in the Eurasian North // A Circumpolar Reappraisal: The Legacy of Gutorm Gjessing (1906-1979). BAR International Series, 2154. Oxford, 2010. P. 189-217. 
ples in this area, many of whom arrived from the south and east. We know from written documents ${ }^{29}$ that Mansi hunters (known then as Yugra) on the Ural slopes and in the Mezen-Pechora River basin were bark canoe builders, but the descriptions are vague. The Eastern Khanty peoples, who lived as hunters and fishermen, seem to have built birchbark canoes in the Narym region until the early $1700 s^{30}$; some Western Khanty hunters, including the Tara near Omsk, may have used them in the taiga forest country until $1886^{31}$. Little is known about these canoes because the appearance of iron following contacts with Russian traders resulted in the Mansi and Khanty switching to expanded log boats with planked sides earlier than the Samoyed.

The coming of new boat technology was part of a wave of social, economic, and political change that occurred when the Russian fur trade expanded into Western Siberia. Trade and European technology, including guns, iron, axes and other useful goods, exacerbated longstanding regional hostilities and often led to interethnic competition. From the $15^{\text {th }}$ through the $17^{\text {th }}$ centuries, northeastern Europe and Western Siberia experienced recurring intertribal warfare, and watercraft played a major role in skirmishes, raids, and all-out battles ${ }^{32}$. Pressure from population movements from the south and east also contributed to conflicts. The arrival of Ugrian peoples east of the Ob River brought hostilities. According to Khanty accounts of the Ob River wars between the Ural Samoyed and the Ugrian peoples circa 1500-1700, Khanty Ugrians using expanded log boats prevailed partly because their archers, who were armed with crossbows, could shoot holes in the Samoyed's bark canoes ${ }^{33}$. The Khanty had replaced their bark canoes with log boats in some parts of the upper Ob before the 1700s. The Selkup (Ostyak Samoyed) also built bark canoes in the Western Siberian taiga. The Selkup bark canoe that Kai Donner collected at the Ket River in 1911-1914 shows Yenisey-type construction, which also appeared in the eastern $\mathrm{Ob}$ basin. Distinctive features of these canoes are use of bird-cherry wood, double layering of the birch-bark bottom, partial decking, and the use of a bent-wood oval insert instead of straight crossways thwarts.

Antropova ${ }^{34}$ assumed - and we concur - that the most recent dispersal of the bark canoe probably occurred in late Iron Age (ca. $500 \mathrm{BCE}$ to $1 \mathrm{CE}$ ) or even later, and probably was centered on Southern Samoyed territory around the headwaters of the Ob, Yenisey, and Lena rivers. Later, there were many other, smaller, shifts in canoe types that resulted in their modern distribution. Various Samoyed groups used bark canoes which would have been known to other people who entered their lands, including Ket and other upper Yenisey groups. Turkic Tatars, the Southern Samoyed's neighbors to the south, may have

${ }^{29}$ Georgi G. J. Beschreibung aller Nationen des Russischen Reichs (Dscription of all Nations of the Russian Empire). St. Petersburg, 1776.

30 Ides E. Y. Three Years Travel over Land from Moscow to China. London, 1706.

31 Granö J. Suomalaisten elämästäSiperiasta. A Letter to Finland from Tomsk, Siberia // The Morning Paper (Newspaper). Finland, August 29, 1886. Available: http://www.migrationinstitute.fi/files/pdf/ suomalaiset_siperiassa/pastori_granon_kirjeita.pdf (accessed: 01.02.2019).

32 Golovnev A. V. Wars and Chiefs Among the Samoyeds and Ugrians of Western Siberia // HunterGatherers in the Modern World: Conflict, Resistance, and Self-Determination. New York; Oxford, 2000. P. 125-49.

${ }^{33}$ Starcev G. Die Ostjaken: Sozial-Ethnographische Skizze. Aus dem Russischen Übertragen von Katharina Oestreich-Geib. München, 1988. S. 5. (First published in 1928 as Study on Vakh River Ostyak, Moskva).

${ }^{34}$ Antropova V. V. Boats. 
adopted the bark canoe from them, as suggested by the Tatars calling the birch-bark canoe a "Samoyed" boat ${ }^{35}$.

Moving east, we leave the canoe traditions of the Ob-Yenisey region and come to the huge Lena River basin and its dominant people, the Sakha, formerly known as Yakut. The Sakha have a mixed bark canoe history owing to their appearance in the Lena valley in the 1300s, arriving from the Baikal region to the south. According to Antropova ${ }^{36}$, the Sakha called their Lena canoe a "Tungus" boat, while linguistic data suggest a western bark canoe heritage related to the Yenisey River $\mathrm{Ket}^{37}$. Sakha groups also settled along the upper Aldan River, where they traded with Chinese and Manchu people by crossing the Stanovoy Mountains to the Zeya River and were introduced to beaked Amur-type canoes.

Environmental conditions partly dictated the origins of these peoples and the directions of their migration routes. The Ob, Yenisey, and Lena rivers were major north-south transport corridors. No less important were the east-west routes created by the Arctic Ocean coast and the east-west-running tributaries of the large rivers, whose headwaters nearly link up between the major river drainages. Travel across these routes was a routine matter by sledge in the winter and by canoe during the rest of the year. In these Central Siberian regions few mountains intervened. Finally, the open Buryat Steppe of north-central Asia south of the Yenisey and Lena headwaters enabled easy movement for horse-based pastoralists and the armies of Central Asian empires and states.

The major dynamic driving population migrations and other movements in Central Siberia, however, was the tumultuous history of cultural interactions channeled by these geographic corridors. During the past 2,000 years, many events resulted in population movements and demographic disruptions. The two most important were the expansion of Turkic-speaking peoples from the Altai Mountain region beginning in the $7^{\text {th }}$ century and the Mongol expansion from the same area in the $13^{\text {th }}$ century. The Turkic expansion reached as far west as the Black Sea and north into the Lena valley, displacing some peoples into the Arctic and assimilating others. The Mongol wars and incursions caused similar disruptions as people were expelled from their homelands. These migrations and displacements were not a new phenomena; they were preceded by similar events linked to the expansion of militarism and pastoral nomadism stimulated by horse domestication in the late Bronze Age and by intensified equestrian conquest in the Iron Age. These movements undoubtedly influenced canoe history, resulting in both demographic movements, such as those of the Ket, the Evenk, and the Sakha, and cultural exchanges, seen in, for instance, the sharing of Lena traditions with Yenisey peoples and in similarities between the Lena and Amur versions of the birch bark canoe seen in the partially-covered decks of the Chuni Western Evenk canoes from the Niblet River (Krasnoyarsk Krai Museum photo 028-009-2107).

The easternmost birch bark canoe users were the Yukagir, who were in the late $19^{\text {th }}$ century a remnant of a much larger people living on the upper and lower Kolyma River in northeastern Siberia, where they speared reindeer at river crossings from bark canoes, skin kayaks, or log boats. They originally lived east of the Yenisey, north of Lake Baikal

${ }^{35}$ Belgibaev E.A. Chelkantsy Landshaft i Cul'tura // Iazyki korennykh narodov Sibiri. Chelkan Collection. Novosibirsk, 2004. P. 102-126.

${ }^{36}$ Antropova V. V. Boats.

37 Sieroszewski W. The Yakut: An Experiment in Ethnographic Research. The Economic Bases of the Way of Life. Moscow, 1993. 
and next to the Samoyed and migrated (perhaps a millennium ago) from there down the Lena River ${ }^{38}$. During this journey they would have been in contact with the Tungus-Evenk, Even, and Sakha. The Yukagir, who were still making birch bark canoes along the upper Kolyma River in 1827, probably acquired their boat traditions from contact with the Samoyed around Lake Baikal.

South of the Yukagir were the Evenk, who inhabited a large swath of territories in the upper Amur, Lena, and Yenisey drainages of Eastern Siberia. As might be expected from their large distribution, the Evenk have an equally complicated bark canoe history that includes many boat types. The origin of the western Tungus-Evenk peoples, who entered Yenisey lands from the south and east, is unclear, but they probably learned to build Yenisey bark canoes by contact with the Ket, the Assan, and other Yeniseyan peoples along the Angara River ${ }^{39}$.

While these reconstructions are speculative and based largely on linguistic and oral history, Western Evenk bark canoes in the Lower and Stony (Podkamennaya) Tunguska rivers belong to the Yenisey type. The border between the Yenisey and the Lena canoe regions ran along the Vitim and Olekma rivers, where both types were known. West of the Vitim, around Lake Baikal and along the Kirenga and Lena headwaters, the Yenisey type was dominant, whereas along the Lena River proper, east of the Vitim confluence, the Lena canoe was prevalent ${ }^{40}$. East of the Yenisey River, various Evenk hunting peoples were the main users of birch bark canoes, and they kept this tradition alive until the early 1900s, when they adopted expanded log boats.

Canoe sizes varied considerably in these large river basins. Some bark canoes were very large, but most were small, usually only two or three meters long, and were built for one or two persons so the canoe could be easily carried over portages. Some boats were made narrow and fast to transport hunters, while others were wide and slow, serving as freighters. The largest birch-bark canoe we know of in Northern Eurasia was an archaeological find built by Evenk hunters along the Maya River, the easternmost Lena tributary; it is 15 meters long and was found at Ust-Maya village in 2001, probably having been made less than 20 years earlier ${ }^{41}$. The canoe has not survived, but it was identified as being a 70-centimeter-wide Amur Type I beaked canoe.

In the Far East, the birch-bark canoe persisted into the $20^{\text {th }}$ century. In old Manchuria, in the basin of the Amur (Heilongjiang) River and along its many tributaries in Russian, Chinese, and Outer Mongolian territory, Tungus-related peoples such as the Manchu, Nanay, and Negidal once constructed similar versions of the beaked Amur canoe. Most were small single-person vessels used for hunting and fishing. Drawings document some canoes from the Chinese Qing (Manchu) dynasty.

\section{Elm and Larch Bark Canoes}

Canoes made of other bark than birch represent a line of canoe development about which much less is known. Archaeological finds and documented descriptions across

38 Ushnitsky V.V. The Whole Truth about the Tungus and Their History (Vsya Pravda o Tungusakh i ikh Istorii). Available at: http://merkit.livejournal.com (accessed: 01.02.2019).

39 Forsyth J. History of the Peoples of Siberia: Russian's Northern Asian Colony 1581-1990. Cambridge, 1994.

40 Antropova V. V. Boats.

${ }^{41}$ Abakumov S. On Orels Track // From the History of Ulusov of Yakutia. 2001. P. 1-6. 
Northern Eurasia identify canoes made of elm, larch, pine, spruce, and aspen. These boats may have had more limited use in time and distance - for instance, for a single crossing of a river - or when birch bark was not available.

The "alternative path" theory for non-birch-bark canoes was suggested by a unique archaeological find on the Viskan (Byslätt) River in Swedish Västergötland, which may be the only elm-bark canoe known in Europe. This fragmented canoe was discovered eroding from a riverbank in 1934 and was between three and five meters long, with slender ribs of hazel branches fastened into the gunwales with wooden pegs; remains of leather were also present. Maria Lindberg ${ }^{42}$ reexamined this find, which was radiocarbon-dated to the late Bronze Age, circa 900 to 800 BCE. No birch bark canoes (and only a handful of conventional log boats) are known in southern Sweden.

Another example of canoes made from other types of bark comes from the old city of Novgorod in northwestern Russia. Here archaeologists found the remains of three composite canoes beneath the walls of the Vladimir Tower, which dates to $1044 \mathrm{CE}$. Study of the best-preserved canoe revealed a thin, expanded log hull measuring 675 by 90 by 55 centimeters covered with glued-on aspen-bark panels ${ }^{43}$. The Vladimir Tower boats may be the most extraordinary small boats in Europe since the canoes combine all the known technologies of their day. Each vessel was a thin-hulled log boat with sewn planks supported by wooden ribs and covered by an outer layer of aspen bark and an inner layer of hide. Their elaborate construction suggests they may have had a special use.

\section{The Ainu Yachip Birch-Bark Canoe}

Adney and Chappelle ${ }^{44}$ described North American Indian elm- and pine-bark canoes in addition to birch-bark ones, and some Northern Eurasian groups, too, used bark other than birch. Information about elm-bark canoes in Eurasia is scarce, except in Hokkaido, where it was used extensively for impromptu boats and other purposes by the Ainu. Nishimura ${ }^{45}$ noted that the basic Ainu boat, a dugout craft known as a chip, closely resembled dugouts of the ancient Evenk-related Japanese. Besides log chips, the Ainu used builtup versions called mochips, hollowed-out tree trunks to which planks were stitched on either side ${ }^{46}$. Ainu log and planked boats existed on Sakhalin Island into the $19^{\text {th }}$ century; Chepelev ${ }^{47}$ studied them and other wooden boats of the Far East. Nishimura documented the Ainu elm-bark canoes that preceded and then persisted alongside log and plank boats following their introduction from mainland Asian via Japanese, Korean, and Manchurian influences.

${ }^{42}$ Lindberg M. The Byslätt Bronze Age Boat: A Swedish Bark Canoe. Master's thesis, Marine Archaeology Programme, University of Southern Denmark, 2012.

43 Troianovskiy S. V., Petrov M. I. The XI Century Boat from Novgorod // Soviet Archaeology. Vol. 2. 1969. P. $1-7$.

44 Adney T. E., Chapelle H. Bark Canoes and Skin Boats of North America. $2^{\text {nd }}$ ed. Washington, 1983.

45 Nishimura Sh. A Study of Ancient Ships of Japan. Pt. 4: Skin Boats. Tokyo, 1931.

${ }^{46}$ Ohtsuka K. Iiaomanochip: Reviving of Boat-Building and Trading Tradition // Ainu: Spirit World of a Northern People. Washington, 1999. P.374-380.

${ }^{47}$ Chepelev V.R. Traditional Means of Waterway Transportation among Aboriginal Peoples of the Lower Amur Region and Sakhalin // Study of Maritime Archaeology. St. Petersburg, 2004. Iss. 5. P. 141-161. 
The Hokkaido History Museum has examples of even simpler bark canoes made of elm bark. This craft has no rib framework; rather, it is structured by a square arrangement, at the top of the boat, of robust sticks attached to a bentwood gunwale-like oval hoop to which bark sheets are fastened at several points. A mat of parallel sticks serves as a flooring to protect the bark bottom. This is the simplest type of bark boat of any we have seen in northern Eurasia and can be imagined as the type of craft that was an early prototype in the evolution of the frame canoe. Its serviceability depends on using elm bark, which is much thicker than any other northern tree bark. Our research also turned up an unusual source of data for Ainu boats: carvings of miniature boats on Ainu ikupasuy prayer sticks. These images are quite common and usually accompany images of large fish and marine mammals. We searched for images of sea-going bark canoes and skin boats among hundreds of $19^{\text {th }}$ and early $20^{\text {th }}$ century ikupasuys, but found none, only images of log and plank boats.

Although elm was unavailable in Northern Siberia, larch was a suitable - if uncommon - alternative to birch. The first academic explorer of Siberia, D. G. Messerschmidt, a German traveling in 1723 on behalf of the RAS, journeyed from New Mangazeya (later renamed Turukhansk) on the Yenisey to the Lower Tunguska River, where he met small groups of Evenk and commented on their bark canoes, some of which he measured and weighed. The Evenk apparently were using larch-bark canoes alongside birch-bark ones; Messerschmidt recorded Evenk larch-bark canoes between the Uchami and Taimura Rivers that were similar in both use and size to those of birch bark; he records one as being 360 by 90 by 30 centimeters.

In 1914, the Dolgan people in Sloika near the Golchikha trading post in western Taimyr used larch-bark canoes, as recorded in an account written by Maud Dorian Haviland ${ }^{48}$. She and an English companion on an ornithology expedition tried to cross a flooded river with their Dolgan guides in larch bark canoes. The Dolgan and Nganasan used similar small boats for hunting birds on Taimyr lakes, where birch bark is not available. Her report shows that larch canoes were common even in the northernmost tundra of the Russian High Arctic for spearing wild reindeer in rivers and for crossing lakes and rivers with tame reindeer during seasonal migrations. These boats, less than three meters long, were small and light - designed for a single person - and could be carried on a reindeer sledge.

\section{Open Skin Boats and Kayaks}

In addition to hosting bark canoes, Northern Eurasia has an extensive history as a skin boat using region; nearly all major groups in the tundra zone used skin boats at some point in their past, although the intensity and purposes differed as it did in the case of bark canoes. Skin boats were used by Siberian Eskimo, Chukchi, and Koryak peoples and had a wider distribution along the Arctic and Pacific coasts in the past than known from recent history. Open skin boats and kayaks have been reported from most coastal areas of Northern Eurasia, the Sea of Okhotsk, and even parts of the Far East. European, Siberian, and Central Asian peoples inhabiting inland regions also used open skin boats, half-decked canoe-kayaks, and bowl-shaped vessels covered with seal, reindeer, or moose hide.

${ }^{48}$ Haviland M.D. A Summer on the Yenisey. London, 1971. 
In Northern Europe, the Saami people may have an early history of skin boat use, as suggested by Stone Age petroglyphs and folk legends. For many years, Nordic archaeologists interpreted petroglyph images dated between 2,000 to 6,000 years old as depictions of skin boats based on their high sides and profiles similar to Eskimo umiaks. However, because heavy ground stone axes and woodworking gouges have been unearthed in the same areas as the petroglyphs, archaeologists today tend to interpret these images as log boats or expanded log boats with sewn plank additions. Nevertheless, some probably do show skin boats, especially in areas where people once hunted seal and walrus among the broken spring sea ice, where hunters would not have been able to use heavy log boats. There are oral history accounts of Saami skårne-väntse skin boats in Swedish Lapland as well as legends relating to how people used skin boats to cross rivers with their reindeer and to hunt sea mammals along the coast ${ }^{49}$. Although there is no detailed knowledge of Saami skin boats, one archaeological find from Tiisteenjoki village on the Lapua River, along the western Finnish coast, dates to circa $3200 \mathrm{BP}^{50}$. According to Mulk and Bayliss-Smith (2006), skin boats may have been used on the northern Norwegian coast until circa 300 to $600 \mathrm{CE}$, when "Viking" lapstrake boats began to replace them. In interior regions, small skin boats survived in villages of the Vapsten Lapp people in Sweden until the first half of the $19^{\text {th }}$ century ${ }^{51}$.

The Karelians, possibly the closest relatives of the Saami owing to mixing and assimilation, arrived on the Kola Peninsula in the 1200s. They later became skin boat users, especially in the White Sea region. Kalevala runes collected between 1600 and 1850 describe boats covered with "fish" (i. e., seal) skin in several regions inhabited by the Finns, Karelians, and Ingrians from the Gulf of Bothnia and the White Sea coast.

Russian Pomors, who arrived on the White Sea coast in the $13^{\text {th }}$ century and pushed the Saami, Karelians, and Ingrians farther north, used light canvas-covered plank boats to hunt seal amid spring sea ice until circa 1900 . This fact does not necessarily imply a prior history of skin-covered frame boats; rather, the Pomors may have used skins as a practical way to waterproof their leak-prone sewn or nailed plank boats. Pomor plank boats were six to eight meters in length, and it is likely that their construction incorporated elements of previous Saami and Karelian technology, including seal-skin waterproofing over planks. The boat traditions of the Maritime Pomors are well documented, as is their large-scale sealing industry, which employed thousands of people and hundreds of boats for hundreds of years. Further research may show that both skin boats and sealing or whaling have a deep history in Northern Scandinavia and northwestern Russia. The many river estuaries from Kola to Taimyr, where beluga whales were hunted, have rock engravings whose shapes suggest skin boats.

Fig. 5 shows the types of open skin boats and skin-covered kayaks that existed in most areas of Northern Eurasia. Two major points can be made about their diversity: first, the overriding conclusion is that open skin boats have been used widely along the continent's northern and northeastern coasts, from Europe to the Amur River and the Sea of Okhotsk

49 Westerdahl Ch. Sewn Boats of the North: A Preliminary Catalogue with Introductory Comments. Part I // International Journal of Nautical Archaeology and Underwater Exploration. No. 14(1). 1985. P. 3362; Sewn Boats of the North: A Preliminary Catalogue with Introductory Comments. Pt. II // International Journal of Nautical Archaeology and Underwater Exploration. No. 14(2). 1985. P. 119-142.

50 Itkonen T.I. Suomen Ruuhet: 1-, 2-, 3-Ja Monipuiset Sekä Lautaruuhet Kivikaudesta Vuoteen 1940.

51 Whitaker I. The Scottish Kayaks Reconsidered // Antiquity. No. 51(201). 1977. P.41-45. 
SCANDINAVIA / WHITE SEA

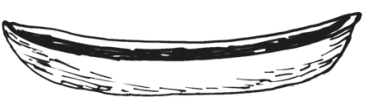

NOVGOROD - RUSSIAN 1300

Plank, Bark, Skin

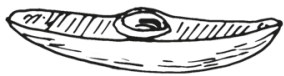

NENETS - KHANTY 1833

Skin decked log boat

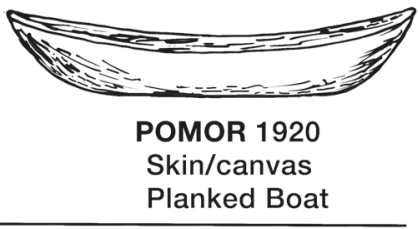

Skin/canvas

Planked Boat

WEST/CENTRAL SIBERIA

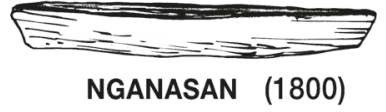

Skin -Covered log Boat

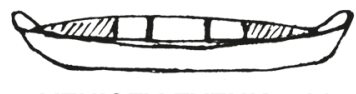

YENISEY EVENK 1927

Skined-decked canoe

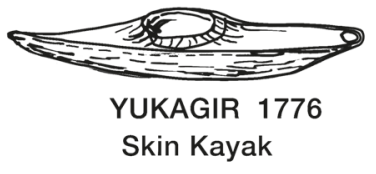

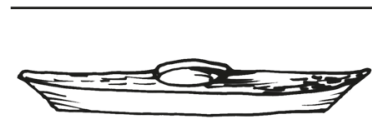

REINDEER CHUKCHI 1900

Skin Kayak

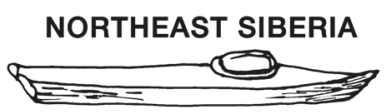

SIBERIAN YUPIK 1905

Skin Kayak

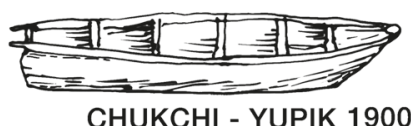

Skin Boat

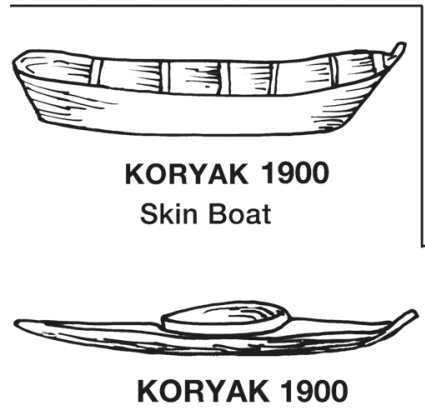

Skin Kayak

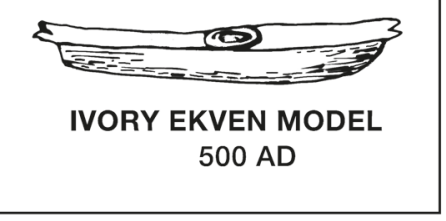

KURIL / KAMCHATKA

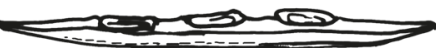

ALEUT KODIAK / KURIL 1840

Skin Kayak

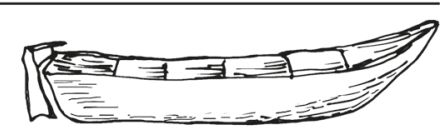

KEREK 1750

Skin Boat

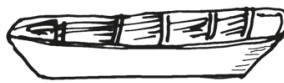

KURIL-KAMCHATKA 1900

Skin Boat

FAR EAST / AMUR

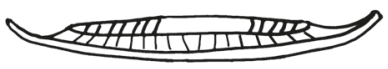

NANAI-GOLDI 1900

Skin-decked Bark Canoe

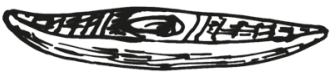

UDEGE 2005

Log Boat, Skin cover

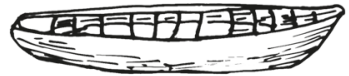

NIVKH-SAKHALIN 1931

Skin Boat Bakry)

Fig. 5. Skin Boats of Northern Eurasia and the Far East (drawing by Harri Luukkanen and Marcia

wherever sea ice was seasonally present. Second, skin-covered kayaks and canoe-kayaks built for individual use in a cold marine or tundra environment were also widely distributed throughout these territories and were used for sea mammal hunting along the coast and for reindeer hunting on lakes and rivers. Inland versions were usually covered with reindeer or moose hide rather than seal skin. Although archaeological evidence is needed for confirmation, historical sources documenting Stephen Burough's voyages to the Kara 
Sea in 1556-1557 $7^{52}$ and Pierre Martin de la Martinière's voyage ca. $1753(1706)^{53}$ indicate that before 1500, skin boats and kayaks were used along the entire Arctic Ocean coast and were not restricted to the historically-known Eskimo territories around Chukotka and Bering Strait. The widespread distribution of these watercraft raises the obvious question of their age and place of origin.

We know little about skin boats in Western Siberia, although the Samoyed along the Arctic Ocean coast, who had long been sea mammal hunters and fishermen, reportedly used such boats. Until the late 1800s, the Nenets (Yurak Samoyed) hunted and fished in the Ob River estuary and off the Yamal Peninsula in decked composite kayaks (log boat hulls decked with seal skins). They may also have used open boats (about which we do not have details). For the Tundra Nenets, farther north, seal and walrus hunting was an important seasonal activity. In the Ob River estuary, the Tundra Nenets shared their hunting grounds, skills, and boats with the Sea Khanty, who - according to accounts written by polar travelers like Alexdander Schrenk (1848) and Timotheus Klingstedt (1769) - hunted beluga in the lower part of the river and in Ob Bay.

East of the Ob estuary are the maritime territories of the Enets (Yenisey Samoyed). Johan Balak ${ }^{54}$ documented their skin boats when he described the journey of the polar explorer and sailor Olivier Brunel, who met Samoyed paddling skin boats on the open sea near the Taz Peninsula 1576. The Nganasan of the Yenisey estuary used small open skin boats for hunting ducks on lakes and spearing reindeer at water crossings ${ }^{55}$.

Our study leads us to believe that before AD 1500 skin boats were used from the Barents Sea to the Anadyr River in Chukotka. This zone included the western regions inhabited by the Nenets, Enets, Nganasan, and Yukagir. Nenets, Sihirtia, and Mansi peoples, all of whom lived along the Barents Sea coast, may have provided connections between the Western Scandinavian pre-Saami skin boat users, while the Yukagir east of Taimyr carried this connection to the Siberian Eskimo and the Pacific tribes as far south as the Sea of Okhotsk. Evidence for the use of skin boats by the Enets and Nganasan, like the case for skin boats in the Sea of Okhotsk, the Kuril Islands, and southern Kamchatka Peninsula, is scant compared to the rich records for their use on the Chukchi Peninsula and in the Bering Strait region.

According to Antropova's classification, Siberian Yupik and Chukchi open skin boats were identical, while the Koryak boats had a different design and construction. Building a large open skin boat or kayak in the treeless tundra required lengthy preparation, including procuring wood for the frame and skins for the cover and gaining the cooperation of several builders and skin sewers. Furthermore, skin boats needed special care and maintenance; on long trips they had to be dried frequently to prevent stretching of the skins and leakage, and their skins and lashings needed constant adjustment and rapid repair when they were torn or punctured.

52 Burough St. The Voyage of the Foresaid M. Stephen Burough, An. 1557 // The Principal Navigations, Voyages, Traffiques, and Discoveries of the English Nation. Cambridge, 2014. P.363-375.

53 Martinière P. M. de la. A New Voyage to the North. London, 1706.

${ }^{54}$ Balak J. Journey into Siberia and to the River Ob, 1581. Available: www.vostlit.info/Texts/rus16/ Merkator/brief_balak_20_02_1581.htm (accessed: 01.02.2019).

55 Simchenko Y. B.: 1) Nganasans // Materialy K Serii "Narody i Kul'tury. No. XXIII. 1976. P.35-37;

2) The Culture of Reindeer Hunters of Northern Eurasia. Moscow, 1976; Popov A. A. The Nganasans // The Peoples of Siberia. Chicago, 1964. 
The close connection between the Siberian Yupik and the Chukchi since the 1600s may have resulted in transfer of the Eskimo kayak and open skin boat designs to the Chukchi. Although the Siberian Eskimo ceased building kayaks in the late 1800s and switched exclusively to the large open angyapit, Chukchi inland and maritime groups continued to use kayaks for hunting on rivers and lakes into the early $20^{\text {th }}$ century. Compared to the longer and more slender Chukchi and Eskimo type, the Koryak kayak was short and wide; it survived as a hunting boat in Penzhina Bay, in the northern Sea of Okhotsk, until the 1920s. The Tungus-Even people adopted this kayak, as well as the large open Koryak skin boat, when they came to Koryak lands on the Okhotsk coast. In all, only a few Chukchi and Koryak kayaks have survived in museums, and only a single Siberian Yupik kayak is known because their use had been replaced by angyapit which were more suitable for whale and walrus hunting.

Another maritime culture, the Itelmen (or Kamchadal) of Kamchatka, employed open skin boats of both the baidar and kayak types. Like the Yukagir, they have a long history in a large and rich land, but introduced diseases and attacks by other Native groups and by Russians entering their lands decimated them. The Itelmen used large skin boats for sea hunting and fishing until the 1800s, and we have some knowledge of their decked kayaks, which they may have shared with the Kushi (Kuril Ainu) and possibly the Hokkaido Ainu. The Nivkh, residing on the Sea of Okhotsk coast and Sakhalin Island, were probably also part of this skin boat maritime culture, but they stopped using such craft before they could be documented. A photograph taken on southern Sakhalin Island, then in Japanese hands, shows two large open skin boats ${ }^{56}$, but their construction details are not clear enough in the photograph to allow detailed description.

We have found a drawing of a two-horned Yukagir decked skin kayak in Georgi's 1776 description of Siberian peoples that has been overlooked in canoe literature (Fig. 6). This kayak, from east of the Lena delta, is very similar to the miniature ivory kayak models excavated from the ca. 500 years CE. Old Bering Sea culture site at Ekven, on Chukotka's East Cape (Fig. 7). Both models show gunwales protruding from bow and stern. The form of the two-horned Yukagir boat suggests design continuity with this ancient Eskimo-Chukchi boat, for these horns are a diagnostic feature of modern angyapik/ umiak construction.

A new find demonstrating likely evidence of skin boats comes from an engraved whalebone artifact found at the Un'en'en site near Nunligran, Chukotka. The artifact came from the floor of a house excavated by Sergei Gusev, radiocarbon-dated to ca. 1,000 BCE and shows engraved images of hunters harpooning large whales ${ }^{57}$ (Gusev pers. comm.). Given the treeless Chukotka coastal environment, it is reasonable to suppose that skin boats are represented. The find is controversial because identical images are only known from Punuk and Thule sites in Alaska and Okhotsk culture dating $1000 \mathrm{calCE}$, making the Un'en'en find 1500 years older than the appearance of whaling harpoons and skin boat models at Ekven. Nevertheless, it is of comparable age to harpoon cradles and kayak fittings indicating skin boats were present at 3000 year old Choris sites in Alaska.

Beyond the sea coast, the Evenk and Mongol peoples had a skin boat culture as well. Skin boats have been documented in the lower Yenisey and upper Lena basins, and in

${ }^{56}$ Nishimura Sh. A Study of Ancient Ships of Japan. Fig. 60.

57 Witze A. Whaling Scene Found in a 3000-Year-Old Picture // Nature News. Available: https://www. nature.com/news/2008/080331/full/news.2008.714/box/1.html (accessed: 01.02.2019). 


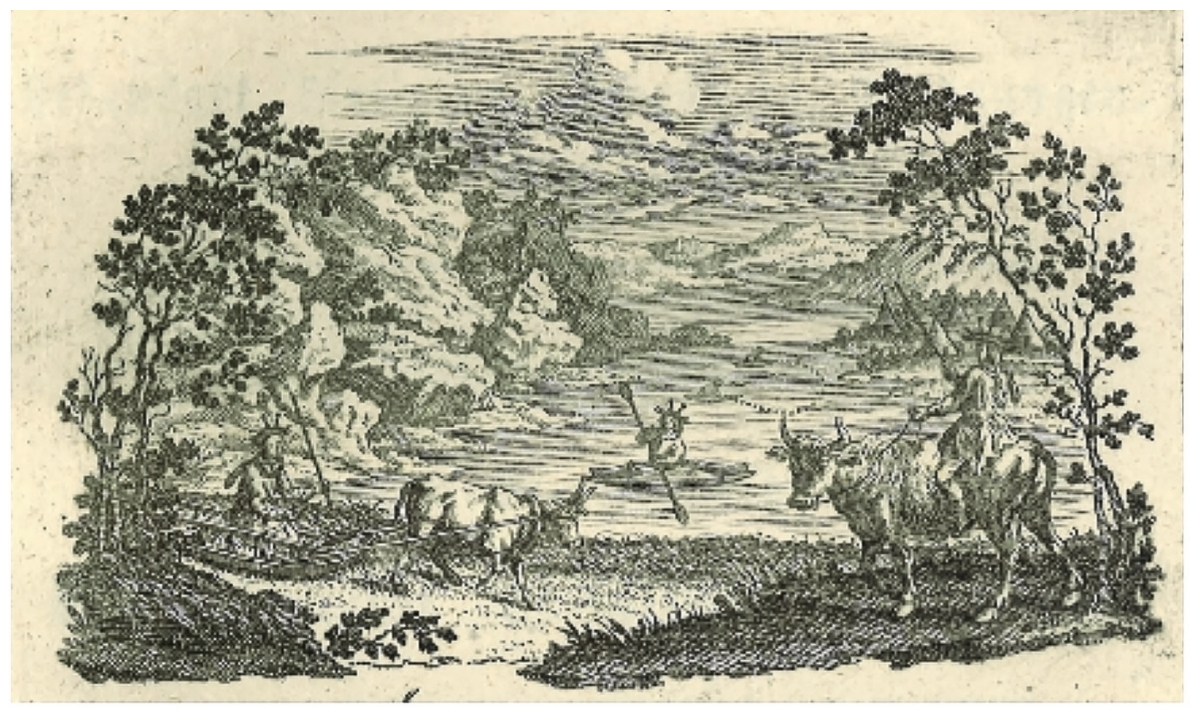

Fig. 6. Yukagir Historical Scene with Two-Pronged Kayaks. Johan Gottleib Georgi (1776) included this illustration in his discussion of the Yukaghir, although it may represent Sakha. The romanticized scene shows conical tents, domesticated cattle, and people with tri-pointed headgear paddling and fishing in skin kayak-like boats. These boats have the same type of bifurcated bow and stern seen in modern Inuit umiaks and ritual boat carvings from the 1,500-year-old Ekven Old Bering Sea Eskimo site near East Cape, Chukotka [Georgi, 1776: 271]

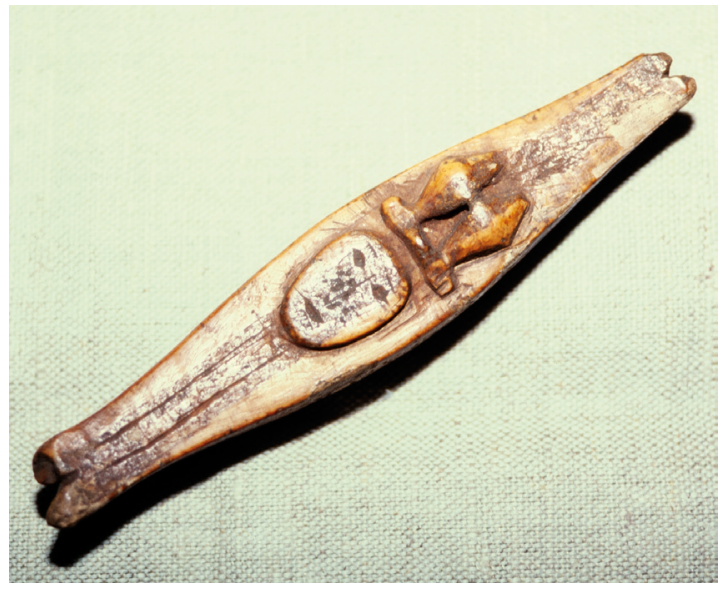

Fig. 7. Spirit Boat from Ekven. This ivory Old Bering Sea model from a Grave 10/11 at Ekven, near East Cape, Chokotka, and a second example from the same site, are the earliest examples Eskimo skin boats. The model shares features of both a kayak (covered deck, cockpit, float gear) and an open skin boat (gunwale extensions, side profile). The human-face and whales on the deck suggest this is a spirit boat with a symbolic, not realistic, function. (Photo: E. V. Anishtchenko [Arutiunov, Sergeev, 1975, pl. 48]) 
Amur-Manchuria and northern Mongolia a similar skin boat culture has a deep history. Most interesting from an evolutionary perspective is the skin boat type we call a canoe-kayak, which has a self-supporting structure and fore and aft decks. It was known among the Chuni-Evenk people who resided between the Angara and Stony Tunguska rivers. Their canoe-kayak was constructed with thin, closely spaced stringers and ribs and was partially decked with reindeer skins or birch bark. The Chuni-Evenk may have originally come here from the Amur region, for a similar construction is seen in the Amur II-type canoe, which also has bow and stern half decks covered with deerskins or birch bark. As suggested by Otis Mason, the decked canoe of the Kootenai Indians of British Columbia suggests possible ancestry with the Amur decked canoe.

Manchu or mixed Evenk and Tungus-Mongol heritage could explain the presence of skin boats in the Far East - including, perhaps, the Korean Peninsula and Japan, whose skin boat history is documented in Chinese records. These records ${ }^{58}$ describe the ethnographic and probably ancient use of rafts buoyed by hides filled with straw or wool and air by horse people of the steppe, especially the Mongols and their neighbors ${ }^{59}$. Since ancient times, Central Asian people have used open coracle-like, wicker-framed skin boats for crossing rivers, and modern Tibetans still use yak-skin boats for fishing and downriver transport of people and freight. Air-filled skins also supported rafts used for downriver cargo transport on the Yellow River and other large rivers in China. Construction and use of these rafts in the rivers of the Far East differed completely from the framed skin boat traditions in Northern Eurasia, and none of these Far East boats could be used for propelled travel. These Far East and Central Asian coracle-type boats probably once existed throughout the steppe, forest, and tundra zones of Eurasia as the Paleolithic prototype for the more highly engineered boats including bark canoes and skin boats. Even in the $20^{\text {th }}$ century people caught without time or tools to fabricate a canoe made simple coracles out of alder or birch withies covered with caribou skins to cross rivers. Examples of this living tradition can be seen in the impromptu bark boats of the Ainu, used for crossing rivers that consist of little more than a folded piece of elm bark supported by a light framework of gunnel-like sticks.

\section{Summary: East Meets West}

Our summary ends with a question: why is the history of bark and skin boats in the northern region of the Eurasian Far East so different from that in the continent's northwestern extremes around the Baltic and White Sea? To put it another way: why have so few of these highly serviceable craft been documented during the past 1,000 years in Fennoscandia, with virtually none persisting into the recent historical era, while in the Far East bark boats dominated the interior waterways into the $20^{\text {th }}$ century?

Part of the answer lies in the types of available records. Written records exist in Fennoscandia only from medieval times, and archaeological finds consist mostly of paddles. Here, bark and skin boats were mostly replaced during the Iron Age, and few excavated boats have been found dating to the succeeding 1,500 years. In Eastern Siberia and along its Arctic and Subarctic coasts, bark canoe and skin boat use continued into mod-

${ }^{58}$ Nishimura Sh. A Study of Ancient Ships of Japan.

59 Sinor D. On Water-Transport in Central Eurasia // Ural-Altaische Jahrbücher. 1961. Vol.33. P. 156179. 
ern times, and both types of craft have been studied and documented, although few are known archaeologically. A wealth of data no doubt exists in Chinese and Manchurian literature dating back to the Iron Age, but this information is not accessible to researchers lacking Chinese or Manchurian language.

However, factors other than archival data are also involved. In Northern Europe, planked boats built with iron nails on a keel rather than a log base were introduced 2,000 years ago, stimulated by developments in the Mediterranean ${ }^{60}$. In northern Europe, lapstrake boats with overlapping planks with sewn seams and then in Viking times with nails, produced strong, light boats of all sizes following a single basic hull design. The smaller versions, for one or a few people, were more durable, and therefore safer, than bark or skin boats and quickly replaced them. Once iron tools and nails became accessible to local builders, plank log boats and clinker boats supplanted birch- and larch-bark canoes, first in the Baltic region by 1500, and soon afterward replaced skin boats along the Arctic coast of western Eurasia.

Unlike in Northern Europe, in the quieter waters of the Amur basin bark canoes continued in regular use into the $20^{\text {th }}$ century for hunting, fishing, and travel. Efficiency and Native economies were the dominant factors in their preservation. Birch bark was readily accessible and could be fashioned into a hunting or fishing craft with just a few days' work. Their persistence in the Far East resulted from social, economic, and political factors related to the maintenance of traditional lifeways, economies, and settlement patterns, and especially the absence of industrialization and commerce once away from the coast and the main Amur artery. As in Europe, boats with nailed or stitched planks also began to supplant bark canoes in the flat-water parts of the Amur system, but these changes did not reach peoples of the northern interior until the $19^{\text {th }}$ century. Where hunters had to navigate rapids and portage between lakes and tributaries, the bark canoe - easy to build, requiring few tools or nails, and extremely light, with no cost for materials - remained the boat of choice into the $20^{\text {th }}$ century.

Bark canoes have been an influential factor connecting peoples from Northern Europe to Chukotka and the Far East. They probably spread throughout the northern parts of the continent even before the final retreat of Ice Age glaciers more than 10,000 years ago and must have entered North America with the first Asian immigrants. Life in the taiga and boreal forests, with their extensive swamps and waterways, was impossible without the bark canoe. Its success continued until canvas, fiberglass, and aluminum replaced bark and wooden frames. Yet even with improved materials, following the same basic design style, canoes remain an integral part of modern life in the forest zone, even far south of the northern forests.

Skin boats and kayaks had the same level of importance for northern coastal peoples as canoes had for boreal peoples. From a construction point of view, the skin boat must have evolved from what people learned earlier in the forest zone from bark canoe building. The skin boat was the only feasible means of travel, migration, hunting and fishing in the rough, ice-infested waters of the northern marine environment. Extensive studies of the Eskimo-type kayak have been made across its range from Northeast Asia to Alaska and Greenland by Rousellot, Zimmerly, Golden, Heath, Kankaanpää, and others, and many theories of its origin have been proposed, but none with definitive proof. It is

${ }^{60}$ Crumlin-Pedersen O. Archaeology and the Sea in Scandinavia and Britain: A Personal Account // Maritime Culture of the North 3. Roskilde, 2010. 
unclear whether a single skin boat technology was shared throughout the Eurasian Arctic, but there is no doubt that after its refinement by Eskimo cultures in the Bering Sea it spread as a single tradition throughout the North American Arctic and Greenland. This technology represents one of the finest examples of nautical design (especially as seen among the Aleut/Unangan) known in the preindustrial world.

Today, bark canoe craftsmen like Henri Vaillancourt (www.birchbarkcanoe.net; see also John McPhee's The Survival of the Bark Canoe) ${ }^{61}$ and a host of skin boat-builders and researchers produce, describe, and promote the use of bark canoes and skin boats of indigenous design. The success of Tappan Adney and Howard Chapelle's North American compendium attests to the undying interest among scholars, enthusiasts, and canoe/ kayak-builders who celebrate the ingenuity of northern craftsmen and the profound influence their boats had on human history. This revolutionary technology, originally inspired and made possible by the birch tree and animal skin, turned rivers and oceans into highways, made possible the discovery and exploitation of new lands, and connected peoples and cultures long before conveyances other than human feet existed. Two facts guarantee the legacy of Northern Eurasian canoes and skin boats: the settlement of the Americas and the continuing use of canoes and kayaks today. Together they are a fitting legacy for a craft that changed the world.

\section{References}

Abakumov S. On Orels Track. From the History of Ulusov of Yakutia, 2001, pp. 1-6.

Adney T.E., Chapelle H. Bark Canoes and Skin Boats of North America. 2 ${ }^{\text {nd }}$ ed. Washington, D.C., Smithsonian Institution Press, 1983, 242 p.

Antropova V. V. Boats. Historical-Ethnographic Atlas of Siberia. Eds M. G. Levin, L. P. Potapov. Moscow, Nauka, 1961, 497 p.

Arnold B. Les pirogues kapepe, l'espace nautique du bassin de la rivière Malagarasi (Tanzanie) et quelques observations sur les pirogues en écorce d'Afrique orientale. Le Locle, Editions G d'Encre, 2014, 68 p.

Arutiunov S. A., Sergeev D. A. Problems of Ethnic History in the Bering Sea: The Ekven Cemetery. Translated by Richard L. Bland. Anchorage, Alaska, Shared Bering Heritage Program, 2006, 262 p.

Belgibaev E. A. Chelkantsy Landshaft i Cul'tura (Chelkantsy: Landscape and Culture). Iazyki korennykh narodov Sibiri. Chelkan Collection. Novosibirsk, Barnaul, Altai State University Press, 2004, pp. 102126. (In Russian)

Belyavsky F. O. A Trip to the Arctic Sea. St. Petersburg: Lazarevs' Institute of Foreign Languages, 1833,259 p.

Brindley H. H. Notes on the Boats of Siberia. Mariner's Mirror, 1919, no. 5(4), pp.66-72; no. 5(5), pp. 130142 ; no. 5(6), pp. 184-187.

Burov G. M. On Mesolithic Means of Water Transportation in Northeastern Europe. Mesolithic Miscellany, 1996, vol. 17, no. 1, pp. 5-15.

Burough St. The Voyage of the Foresaid M. Stephen Burough, An. 1557. The Principal Navigations, Voyages, Traffiques, and Discoveries of the English Nation. Ed. by R. Hakluyt. Cambridge, Cambridge University Press, 2014, pp.363-375.

Christensen A.E. Ships and Navigation. Vikings: the North Atlantic Saga. Eds W. Fitzhugh, E.I. Ward. Washington, D. C., Smithsonian Institution Press, 2000, pp. 86-97.

Chepelev V.R. Traditional Means of Waterway Transportation among Aboriginal Peoples of the Lower Amur Region and Sakhalin. Study of Maritime Archaeology. St. Petersburg, Russian Academy of Sciences, 2004, no. 5, pp. 141-161.

Crumlin-Pedersen O. Archaeology and the Sea in Scandinavia and Britain: A Personal Account. Maritime Culture of the North 3. Roskilde, Viking Ship Museum, 2010, 184 p.

De Lisle N., Königsfeld T. Extract de Voyage un Sibirie M. DeLisle \& Journal de M. Königsfeld en 1740. Francois Antoine (1768), Histoire générale des voyages, voyage de Sibiria. Paris, Chez Didot, pp. 525-527.

61 McPhee J. The Survival of the Bark Canoe. New York, 1975. 
Forsyth J. History of the Peoples of Siberia: Russian's Northern Asian Colony 1581-1990. Cambridge, Cambridge University Press, 1994, 445 p.

Foss M.E. Kul'turnye sviazi severa Vostochnoi Evropy vo II tysiacheletii do nashei ehry. Sovetskaia Etnografiia, 1948, vol. 4, pp. 23-35.

Georgi G. J. Beschreibung aller Nationen des Russischen Reichs (Dscription of all Nations of the Russian Empire). St. Petersburg, C. W. Müller, 1776, 530 p.

Golden H. Kayaks of Alaska. White Horse Grocery Press, 2015, 560 p.

Golovnev A. V. Wars and Chiefs Among the Samoyeds and Ugrians of Western Siberia. Hunter-Gatherers in the Modern World: Conflict, Resistance, and Self-Determination. Eds P.P. Schweitzer, M. Biesele, R. K. Hitchcock. New York, Oxford, Bergham Books, 2000, pp. 125-149.

Haviland M. D. A Summer on the Yenisey. London, Ayer Publishing, 1971, 328 pp.

Hornell J. Water Transport: Origins and Early Evolution. Newton Abbot, David \& Charles, 1970, 377 pp.

Itkonen T. I. Suomen Ruuhet: 1-, 2-, 3-Ja Monipuiset Sekä Lautaruuhet Kivikaudesta Vuoteen 1940. Forssa, Kansantieteellinen Arkisto, 1942, 172 p.

Ides E. Y. Three Years Travel over Land from Moscow to China. Ed. by N. Witsen. London, W. Freeman, 1706, $210 \mathrm{p}$.

Jennings J. The Art and Obsession of Tappan Adney. Toronto, Firefly Books, 2004, 152 p.

Johnstone P. The Seacraft of Prehistory. Ed. by Sean McGrail. Cambridge, Harvard University Press, 1980, $260 \mathrm{p}$.

Kankaanpää J. Kajakki. Typologinen Ja Etnohistoriallinen Tutkielma (The Kayak: A Study in Typology and Ethnohistory). Master's thesis, University of Helsinki. Helsingin Yliopiston Kansatieteen Laitoksen Tutkimuksia 15, 1989, $72 \mathrm{p}$.

Klingstädt T. M. Historische Nachricht von den Samojeden und den Lapplä̈dern. St. Petersburg, Hartknoch, $1769,72 \mathrm{p}$.

Lindberg M. The Byslätt Bronze Age Boat: A Swedish Bark Canoe. Master's thesis, Marine Archaeology Programme, University of Southern Denmark, 2012.

Luukkanen H. On the Diffusion of Bark Canoes, Skin Boats and Expanded Log Boats in the Eurasian North. A Circumpolar Reappraisal: The Legacy of Gutorm Gjessing (1906-1979). Ed. by Ch. Westerdahl. BAR International Series 2154. Oxford, Archaeopress, 2010, pp. 189-217.

Martinière P. M. de la. A New Voyage to the North. London, T. Hodgson and A. Barker, 1706, 153 p.

Mason O., Meriden S.H. 1901. Pointed Bark Canoes of the Kutenai and Amur. Report of the U. S. National Museum for 1899, Washington, DC, Government Printing Office, 1706, pp. 525-537.

McGrail S. Ancient Boats in North-West Europe: The Archaeology of Water Transport to AD 1500. New York, Addison Wesley Longman, 1998, $324 \mathrm{p}$.

McPhee J. The Survival of the Bark Canoe. New York, Farrar, Strauss and Giroux, 1975, 160 p.

Mulk I-M., Bayliss-Smith T. The Representation of Sámi Cultural Identity in the Cultural Landscapes of Northern Sweden: the Use and Misuse of Archaeological Evidence. The Archaeology and Anthropology of Landscape. Eds P. J. Ucko, J. Layton. London, Routledge, 1998, pp. 358-396.

Nishimura Sh. A Study of Ancient Ships of Japan. Part 4: Skin Boats. Tokyo, Society of Naval Architects, 1931, $249 \mathrm{p}$.

Ohtsuka K. Iiaomanochip: Reviving of Boat-Building and Trading Tradition. Ainu: Spirit World of a Northern People. Eds W.W.Fitzhugh, C.Dubreuil. Washington D.C., Arctic Studies Center, Smithsonian Institution, 1999, p. 374-380.

Pelikh G. I. Proiskhozhdenie selkupov. Tomsk, Tomsk State University Press, 1972. 424 p. (In Russian)

Popov A.A. The Nganasans. The Peoples of Siberia. Eds M. G. Levin, L.P. Potapov. Transl. by E. Dunn. Chicago, University of Chicago Press, 1964, pp. 571-586.

Ritzenthaler R. E. The Building of a Chippewa Indian Birch-Bark Canoe. Bulletin of the Public Museum of the City of Milwaukee, no. 19(2), 1950, pp.59-98.

Rousellot J.-L. Watercraft in the North Pacific: A Comparative View. Anthropology of the North Pacific Rim. Eds W. Fitzhugh, V. Chaussonnet. Washington, D. C., Smithsonian Institution Press, 1994, pp. 243-258.

Rowley-Conwy P. To the Upper Lake: Star Carr Revisited - by Birchbark Canoe. Economic Zooarchaeology: Studies in Hunting, Herding, and Early Agriculture. Eds P. Rowley-Conwy, D. Serjeantson, P. Halstead. Chapter 23. Oxford, Oxbow Books, 2017, pp. 197-207.

Rudenko S.I. Early Harpoon Heads of the Asiatic Eskimo. Sovietskaia Etnografiia. Moscow, Izdatel'stvo Akademii nauk SSSR, 1947, vol. 2, pp. 33-56.

Schrenk L. Reisen und Forschungen im Amur-Lande. Bd.3: Die Völker des Amur-Landes. St. Petersburg, Russian Academy of Science, 1881, 310 p. 
Sieroszewski W. The Yakut: An Experiment in Ethnographic Research. The Economic Bases of the Way of Life. Moscow, Nauka, 1993, 713 p.

Simchenko Y. B. Nganasans. Materialy k Serii "Narody i Kul'tury. Vol. XXIII. 1976, pp. 35-37. (In Russian)

Simchenko Y. B. The Culture of Reindeer Hunters of Northern Eurasia. Moscow, Nauka, 1976.

Sinor D. On Water-Transport in Central Eurasia. Ural-Altaische Jahrbücher, 1961, no. 33, pp. 156-179.

Sokolova Z. P. The Mansi. Moscow, Nauka, 1983, 322 p. (In Russian)

Starcev G. Die Ostjaken: Sozial-Ethnographische Skizze. Aus dem Russischen Übertragen von K. OestreichGeib. Transl. by K. Oestreich-Geib. München, Veröffentlichungen der Congregatio Ob-Ugrica, 1988, $103 \mathrm{~S}$.

Tambets K. et al. The Western and Eastern Roots of the Saami-The Story of Genetic 'Outliers' Told by Mitochondrial DNA and Y Chromosomes. American Journal of Human Genetics, 2004, vol. 74, iss. 4, pp. 661-682.

Trebitsch R. Fellboote und Schwimsäcke und Ihre Geographische Verbreitung in der Vergangenheit und Gegenwart. Archiv für Anthropologie. Neue Folge, Bd. XI., Braunschweig, Friendrich Vieweg \& Sohn, 1912, pp. 61-84.

Troyanovskiy S. V., Petrov M.I. The XI Century Boat from Novgorod. Soviet Archaeology, 1969, vol.2, pp. 1-7.

Vermeulen H. S. Ethnography and Empire. G. F. Müller and the Description of Siberian Peoples. Before Boas. The Genesis of Ethnography and Ethnology in the German Enlightenment. Ed. by Han F. Vermeulen, Lincoln and London, University of Nebraska Press, 2016, pp. 131-218.

Westerdahl Ch. Sewn Boats of the North: A Preliminary Catalogue with Introductory Comments. Part I. International Journal of Nautical Archaeology and Underwater Exploration, 1985, no. 14(1), pp.33-62.

Westerdahl Ch. Sewn Boats of the North: A Preliminary Catalogue with Introductory Comments. Part II. International Journal of Nautical Archaeology and Underwater Exploration, 1985, no. 14(2), pp.119142.

Whitaker I. The Scottish Kayaks Reconsidered. Antiquity, 1977, vol.51(201), pp. 41-45.

Статья поступила в редакцию 1 июня 2018 г. Рекомендована в печать 12 марта 2019 г.

Received: June 1, 2018

Accepted: March 12, 2019 